\title{
Comparison of Private Universities in India based on NIRF Ranking and Fee Charging Strategies
}

\author{
P. S. Aithal ${ }^{1}$, Madhushree ${ }^{2}, \&$ Revathi R. ${ }^{3}$ \\ ${ }^{1}$ Srinivas Institute of Management Studies, Srinivas University, Mangalore - 575 001, INDIA \\ ${ }^{2,3}$ Research Scholar, Srinivas Institute of Management Studies, Srinivas University, \\ Mangalore - India \\ E-mail:psaithal@gmail.com
}

Type of the Paper: Case Study.

Type of Review: Peer Reviewed.

Indexed In: OpenAIRE

DOI: http://dx.doi.org/10.5281/zenodo.1098373.

Google Citation: $\underline{\text { IJCSBE }}$

\section{How to Cite this Paper:}

Aithal, P. S., Madhushree, \& Revathi, R. (2017). Comparison of Private Universities in India based on NIRF Ranking and Fee Charging Strategies. International Journal of Case Studies in Business, IT and Education (IJCSBE), 1(2), 72-85.

DOI: http://dx.doi.org/10.5281/zenodo.1098373.

International Journal of Case Studies in Business, IT and Education (IJCSBE)

A Refereed International Journal of Srinivas University, India.

(C) With Authors.

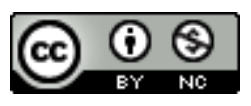

This work is licensed under a Creative Commons Attribution-Non Commercial 4.0 International License subject to proper citation to the publication source of the work.

Disclaimer: The scholarly papers as reviewed and published by the Srinivas Publications (S.P.), India are the views and opinions of their respective authors and are not the views or opinions of the S.P. The S.P. disclaims of any harm or loss caused due to the published content to any party. 


\title{
Comparison of Private Universities in India based on NIRF Ranking and Fee Charging Strategies
}

\author{
P. S. Aithal ${ }^{1}$, Madhushree ${ }^{2}$, \& Revathi R. ${ }^{3}$ \\ ${ }^{1}$ Srinivas Institute of Management Studies, Srinivas University, Mangalore - 575 001, INDIA \\ ${ }^{2,3}$ Research Scholar, Srinivas Institute of Management Studies, Srinivas University, \\ Mangalore - India \\ E-mail: psaithal@gmail.com
}

\begin{abstract}
The need of additional universities in Indian higher education system to provide higher education to all eligible population of the country and the success of private university model in the USA tempted the Indian government to give permission to establish Private Universities in the country. Accordingly, based on section 22 of UGC act, the Indian government has allowed the state governments to establish private universities in the respective states. Presently there are 264 private universities in the country spread over 22 states. Due to non-availability of any financial support from the state and central governments, private universities are trying to sustain through their only strategy of service differentiation through $21^{\text {st }}$ century curriculum and industry integrated programme design. In this paper, we have studied and compared some of the private universities in India in terms of their infrastructure, faculties, variety of courses, and fee structure of identified courses. We have also studied the performance scores given by NIRF, MHRD, Govt. of India for various criterions like Teaching, Learning \& Resources, Research and Professional Practice, Graduation Outcomes, Outreach and Inclusivity, Public Perception. Based on the annual fee charged by the private universities established before 2010, we have identified three types of strategies which include low-cost - low quality, high-fee - high-quality, and nominal-fee high quality strategies and analysed them based on the philosophy and background of such universities in general. We have also identified other innovative strategies offered by many private universities, in general, to differentiate themselves from publicly funded universities. The paper also contains some recommendations based on the observations to improve the quality, relevancy, and effectiveness of educational services and research contributions of private universities.
\end{abstract}

Keywords: Private universities, Business strategies, Growth strategies, Education service differentiation strategy, Innovations \& best practices in higher education and research, Recommendations for private universities.

\section{INTRODUCTION :}

Private universities are contributing to the higher education in many countries and in the United States they have acquired the top university status. As per the recent university ranking in the USA [1], all top ten universities are found to be private universities and sixteen universities out of twenty top US universities are private Universities as shown in Table 1 . The success of the private university model in the USA inspired many countries to do similar experiments in higher education in their countries.

Table 1 : First twenty Top Universities in USA as per 2017-18 US University Ranking [1]

\begin{tabular}{|l|lc|l|l|l|l|}
\hline $\begin{array}{l}\text { S. } \\
\text { No }\end{array}$ & University & Type & $\begin{array}{l}\text { World } \\
\text { Ranking }\end{array}$ & $\begin{array}{l}\text { USA } \\
\text { Ranking }\end{array}$ & Location \\
\hline 1 & Massachusetts $\quad$ Institute $\quad$ of & Private & 01 & 01 & Cambridge, MA \\
\hline
\end{tabular}




\begin{tabular}{|l|l|l|l|l|l|}
\hline & Technology & & & & \\
\hline 2 & Stanford University & Private & 02 & 02 & CA Stanford, \\
\hline 3 & Harvard University & Private & 03 & 03 & Cambridge, MA \\
\hline 4 & California Institute of Technology & Private & 04 & 04 & Pasadena, CA \\
\hline 5 & University of Chicago & Private & 09 & 05 & Chicago, IL \\
\hline 6 & Princeton University & Private & 13 & 06 & Princeton, NJ \\
\hline 7 & Cornell University & Private & 14 & 07 & Ithaca, NY \\
\hline 8 & Yale University & Private & 16 & 08 & New Haven, CT \\
\hline 9 & Johns Hopkins University & Private & 17 & 09 & Baltimore, MD \\
\hline 10 & Columbia University & Private & 18 & 10 & New York, NY \\
\hline 11 & University of Pennsylvania & Private & 19 & 11 & Philadelphia, PA \\
\hline 12 & Duke University & Private & 21 & 12 & Durham, NC \\
\hline 13 & University of Michigan & Public & 21 & 12 & Ann Arbor, MI \\
\hline 14 & University of California--Berkeley & Public & 27 & 14 & Berkeley, CA \\
\hline 15 & Northwestern University & Private & 28 & 15 & Evanston, IL \\
\hline 16 & University of California--Los & Public & 33 & 16 & Los Angeles, \\
& Angeles & & & & CA \\
\hline 17 & University of California & Public & 38 & 17 & San Diego \\
\hline 18 & Carnegie Mellon University & Private & 47 & 18 & Pittsburgh, PA \\
\hline 19 & New York University & Private & 52 & 19 & New York, NY \\
\hline 20 & Brown University & Private & 53 & 20 & Providence, RI \\
\hline
\end{tabular}

During last two decades, Indian government realized the need of additional Universities in the country to provide higher education to all young aspirants and promoted the private University model in the country with the reason that establishment of Private universities id the best solution to this problem in the country without financial burden to the government. Accordingly, based on section 22 of UGC act, the Indian government has allowed the state governments to establish private universities in the respective states. Consequently, 22 states in the country have established private universities and as per UGC information, presently 264 private universities established in the country are competent to award degrees with the approval of the statutory councils, wherever required through their main campus (Table 2). Accordingly, many established private universities in different states of the country have started their higher educational service and formulating their strategies to provide quality and innovative education to attract many students in the areas of high demand in the industry and society. Due to non-availability of any financial support from the state and central governments, private universities are trying to sustain through their own strategy of service differentiation through $21^{\text {st }}$ century curriculum and industry integrated programme design. A good number of research studies are carried out on challenges and opportunities for private universities in India [2 -10]. In this paper, we have studied the activities of private universities in India which include a number of Private universities in different states of the country, strategies of private universities in terms of their infrastructure, a variety of courses, fee structure of various courses, innovative curriculum, quality education through quality faculty, research investments, research promotions and research output, industry \& other institutes collaborations, foreign university \& institutes collaboration, placement services, student involvement of research, and innovation \& best practices [11-25].

Table 2 : Composition of various types of Universities in India as on 05/06/2017

\begin{tabular}{|l|l|l|l|}
\hline S. No. & University Type & Number & Percentage \\
\hline 1 & Central Universities & 46 & $5.8 \%$ \\
\hline 2 & State Universities & 359 & $45.3 \%$ \\
\hline 3 & Deemed Universities & 123 & $15.6 \%$ \\
\hline 4 & Private Universities & 264 & $33.3 \%$ \\
\hline & Total & $\mathbf{7 9 2}$ & $\mathbf{1 0 0} \%$ \\
\hline
\end{tabular}




\section{RESEARCH OBJECTIVES :}

The objectives of this study are :

(1) To know about establishment and distribution of private universities in different states of the country.

(2) Comparison of Private universities in terms of their age, land, and their number of faculty departments.

(3) The position grabbed by Private universities in NIRF best university ranking based on various NIRF overall parameters strengths.

(4) List of private universities included in NIRF-2017 Best Management Institution ranking.

(5) To study Fee charging strategies of these Universities like Low-fees low-cost strategy, High-fees high-quality strategy, and Nominal-fees High-quality strategy etc. established on or before 2010.

(6) To know Private universities having Medical Courses including MBBS along with other UG courses.

(7) Study on innovative curriculum, quality education through quality faculty, research investments, research promotions and research output, industry \& other institutes collaborations, foreign university \& institutes collaboration, placement services, student involvement in research, and innovation $\&$ best practices.

(8) Advantages of innovations and best practices offered by Private Universities for students.

(9) Recommendations to the private universities for improving their performance based on observations to improve the quality, relevancy, and effectiveness of educational services and research contributions.

The data are collected from UGC official website and the official websites of the private universities and the fee structure and other data are mentioned in this paper for the academic year 2017-18. Some of the fee-related data are obtained by personally calling the universities using the telephone numbers mentioned in respective universities websites.

\section{PRIVATE UNIVERSITIES IN DIFFERENT STATES IN INDIA :}

Even though 264 private universities are established in the country through various state government acts, only a few universities could able to establish required infrastructure. As per the survey and the data depicted in table 3, out of 264 private universities established by the year 2017, 90 of them are started before 2010 and remaining are started after 2010. Except few, most of the private universities are now in developing stage and due to heavy competition between public and private universities, are struggling to establish mainly due to financial constraints. Since the investments required on land, infrastructure, and faculty is very high and return on investment is very slow due to heavy competition by government-funded public universities.

Table 3 : Number of Private Universities, States wise started before and after 2010.

\begin{tabular}{|l|l|c|c|c|}
\hline $\begin{array}{l}\text { S. } \\
\text { No }\end{array}$ & State & $\begin{array}{c}\text { No. of Private } \\
\text { Universities }\end{array}$ & Started before 2010 & $\begin{array}{c}\text { Started after } \\
\mathbf{2 0 1 0}\end{array}$ \\
\hline 1 & Arunachal Pradesh & 7 & 0 & 7 \\
\hline 2 & Assam & 5 & 2 & 3 \\
\hline 3 & Chhattisgarh & 9 & 1 & 8 \\
\hline 4 & Gujarat & 27 & 10 & 17 \\
\hline 5 & Haryana & 19 & 4 & 15 \\
\hline 6 & Himachal Pradesh & 17 & 9 & 8 \\
\hline 7 & Jharkhand & 8 & 1 & 7 \\
\hline 8 & Karnataka & 12 & 2 & 10 \\
\hline 9 & Madhya Pradesh & 23 & 4 & 19 \\
\hline 10 & Maharashtra & 6 & 0 & 6 \\
\hline 11 & Manipur & 1 & 0 & 1 \\
\hline 12 & Meghalaya & 8 & 6 & 2 \\
\hline 13 & Mizoram & 1 & 1 & 0 \\
\hline 14 & Nagaland & 2 & 2 & 0 \\
\hline
\end{tabular}


International Journal of Case Studies in Business, IT and Education (IJCSBE), ISSN: 2581-6942, Vol. 1, No. 2, December 2017.

\begin{tabular}{|c|l|c|c|c|}
\hline 15 & Orissa & 6 & 2 & 4 \\
\hline 16 & Punjab & 14 & 3 & 11 \\
\hline 17 & Rajasthan & 30 & 18 & 12 \\
\hline 18 & Sikkim & 5 & 4 & 1 \\
\hline 19 & Uttarakhand & 11 & 5 & 6 \\
\hline 20 & Uttar Pradesh & 28 & 15 & 13 \\
\hline 21 & Tripura & 1 & 1 & 0 \\
\hline 22 & West Bengal & 8 & 0 & 8 \\
\hline \multicolumn{2}{|c|}{ Total } & 90 & 158 \\
\hline
\end{tabular}

4. COMPARISON OF PRIVATE UNIVERSITIES IN TERMS OF AGE, LAND, AND FACULTIES :

The private universities which are funded and managed by financially powerful NGO or by sustained profit-making companies are able to grow at a faster pace. Like in other industrial and service sector, private universities in India follows either 'Low-fee - low-cost strategy', 'High-fee - high-quality strategy', or 'Low-fee - high-quality strategy'.

Table 4 : List of some selected Private Universities based on their age, infrastructure, and the number of faculty/departments established.

\begin{tabular}{|c|c|c|c|c|c|}
\hline $\begin{array}{l}\text { S. } \\
\text { No }\end{array}$ & State & No. of Private Universities & $\begin{array}{l}\text { Year of } \\
\text { Start /UGC } \\
\text { Letter }\end{array}$ & $\begin{array}{l}\text { Land in } \\
\text { Acres }\end{array}$ & $\begin{array}{l}\text { No Faculty/Dept. } \\
\text { Facul }\end{array}$ \\
\hline 1 & $\begin{array}{l}\text { Arunachal } \\
\text { Pradesh }\end{array}$ & $\begin{array}{l}\text { 1. Indira Gandhi Technological } \\
\text { and Medical Science } \\
\text { University }\end{array}$ & 2012 & 83.5 & 03 \\
\hline 2 & Assam & 1. Don Bosco University & 2008 & 500 & 04 \\
\hline 3 & Chhattisgarh & 1. CV Raman University & 2006 & 48 & 11 \\
\hline \multirow[t]{3}{*}{4} & \multirow[t]{3}{*}{ Gujarat } & $\begin{array}{l}\text { 1. Dhirubhai Ambani Institute } \\
\text { of Information and } \\
\text { Communication Technology }\end{array}$ & $2003 / 2004$ & 50 & 01 \\
\hline & & 2. Nirma University & $2003 / 2004$ & 115 & 10 \\
\hline & & 3. Parul University & 2003 & 150 & 20 \\
\hline \multirow[t]{4}{*}{5} & \multirow[t]{4}{*}{ Haryana } & $\begin{array}{l}\text { 1. AMITY University, } \\
\text { Gurgaon }\end{array}$ & $2010 / 2010$ & 110 & 23 \\
\hline & & $\begin{array}{l}\text { 2. O.P. Jindal Global } \\
\text { University }\end{array}$ & $2009 / 2009$ & 80 & 06 \\
\hline & & 3. SRM University, Haryana & $2013 / 2014$ & 48 & 19 \\
\hline & & $\begin{array}{l}\text { 4. G.D. Goenka University, } \\
\text { Haryana }\end{array}$ & $2013 / 2013$ & 60 & 10 \\
\hline \multirow[t]{2}{*}{6} & \multirow[t]{2}{*}{$\begin{array}{l}\text { Himachal } \\
\text { Pradesh }\end{array}$} & $\begin{array}{l}\text { 1. Jaypee University of } \\
\text { Information Technology, } \\
\text { Himachal Pradesh }\end{array}$ & $2002 / 2002$ & 25 & 9 \\
\hline & & $\begin{array}{l}\text { 2. Chitkara University, } \\
\text { Himachal Pradesh }\end{array}$ & $2009 / 2009$ & 17 & 4 \\
\hline 7 & Jharkhand & $\begin{array}{l}\text { 1. The Institute of Chartered } \\
\text { Financial Analysts of India } \\
\text { University, Jharkhand }\end{array}$ & $2008 / 2009$ & 6.8 & 2 \\
\hline \multirow[t]{6}{*}{8} & \multirow{6}{*}{ Karnataka } & 1. Alliance University & 2010 & 40 & 5 \\
\hline & & 2. PES University & 2013 & 25 & 9 \\
\hline & & 3. CMR University & 2013 & 60 & 8 \\
\hline & & 4. Ajim Premji University & 2010 & 12 & 3 \\
\hline & & 5. Reva University & 2013 & 43 & 6 \\
\hline & & 6. M. S. Ramaya University & 2013 & 76 & 7 \\
\hline
\end{tabular}

P. S. Aithal et al. (2017); www.srinivaspublication.com 
International Journal of Case Studies in Business, IT and Education (IJCSBE), ISSN: 2581-6942, Vol. 1, No. 2, December 2017.

\begin{tabular}{|c|c|c|c|c|c|}
\hline & & 7. Srinivas University & 2013 & 45 & 8 \\
\hline \multirow[t]{2}{*}{9} & \multirow{2}{*}{$\begin{array}{l}\text { Madhya } \\
\text { Pradesh }\end{array}$} & 1.Amity University & 2010 & 100 & 12 \\
\hline & & $\begin{array}{l}\text { 2.Jagran Lakecity University, } \\
\text { Bhopal }\end{array}$ & 2013 & 200 & 11 \\
\hline 10 & Maharashtra & 1.Amity University & 2014 & 1200 & 21 \\
\hline 11 & Orissa & 1.Xevier University & 2013 & 37 & 07 \\
\hline \multirow[t]{2}{*}{12} & \multirow[t]{2}{*}{ Punjab } & $\begin{array}{l}\text { 1. Lovely Professional } \\
\text { University }\end{array}$ & 2005 & 600 & 60 \\
\hline & & $\begin{array}{l}\text { 2. Sri Guru Granth Sahib } \\
\text { World University }\end{array}$ & 2008 & 136.75 & 12 \\
\hline \multirow[t]{3}{*}{13} & \multirow[t]{3}{*}{ Rajasthan } & 1. Amity University & 2008 & 152 & 21 \\
\hline & & 2. Manipal University & 2011 & 600 & 14 \\
\hline & & 3. Jaipur National University & 2007 & 120 & 17 \\
\hline 14 & Sikkim & 1. Sikkim Manipal University & 1995 & 33 & 11 \\
\hline \multirow[t]{2}{*}{15} & \multirow[t]{2}{*}{ Uttarakhand } & $\begin{array}{l}\text { 1. University of Petroleum and } \\
\text { Energy Studies }\end{array}$ & 2003 & 42 & 07 \\
\hline & & 2. Himgiri Zee University & 2003 & 50 & 05 \\
\hline \multirow[t]{7}{*}{16} & \multirow{7}{*}{$\begin{array}{l}\text { Uttar } \\
\text { Pradesh }\end{array}$} & 1. AMITY University & 2003 & 110 & 19 \\
\hline & & 2. Bennett University & 2016 & 68 & 06 \\
\hline & & 3. Sharda University & 2009 & 63 & 13 \\
\hline & & 4. Jaypee University & 2001 & 25 & 09 \\
\hline & & $\begin{array}{l}\text { 5.Teerthanker Mahaveer } \\
\text { University }\end{array}$ & 2008 & 140 & 17 \\
\hline & & $\begin{array}{l}\text { 6. Noida International } \\
\text { University }\end{array}$ & 2010 & 75 & 08 \\
\hline & & 7. Golgotias University & 1999 & 52 & 18 \\
\hline
\end{tabular}

\section{PRIVATE UNIVERSITIES IN NIRF RANKING :}

National Institutional Ranking Framework (NIRF) is an Indian government higher educational institutions ranking agency approved by MHRD, The ranking framework proposed a methodology to rank higher educational institutions including Universities across the country. This methodology consists of five parameters for ranking which include (1) Teaching, Learning and Resources, (2) Research and Professional Practices, (3) Graduation Outcomes, (4) Outreach and Inclusivity, and (5) Public perception. The list of private universities included in NIRF-2017 in best universities ranking is listed in Table 5. Only 17 private universities could find a Top ranking position out of 200 Top universities. List of private universities included in NIRF-2017 under best Management Institutions ranking is listed in Table 5. Surprisingly only four management institutions under private universities could secure top ranking out of Top 100 Management institutions (Source : https://www.nirfindia.org/ranking2017.html).

Table 5 : List of private universities included in NIRF-2017 Best university ranking.

\begin{tabular}{|l|l|l|l|}
\hline $\begin{array}{l}\text { S. } \\
\text { No. }\end{array}$ & Name of the University & $\begin{array}{l}\text { NIRF } \\
\text { Rank }\end{array}$ & $\begin{array}{l}\text { Overall Parameter } \\
\text { Based Strength }\end{array}$ \\
\hline 1 & Amity University, Uttara Pradesh & 52 & $39.17 \%$ \\
\hline 2 & Shiv Nadar University, Uttara Pradesh & 60 & $37.95 \%$ \\
\hline 3 & Nirma University, Ahmedabad, Gujrath & 75 & $36.21 \%$ \\
\hline 4 & Jaypee University, Noida, Uttara Pradesh & 81 & $35.69 \%$ \\
\hline 5 & $\begin{array}{l}\text { Jaypee University of Information Technology, } \\
\text { Himachal Pradesh }\end{array}$ & 33 & $34.11 \%$ \\
\hline 6 & PES University, Karnataka & 94 & $33.94 \%$ \\
\hline 7 & Chitkara University Institute of Information and & 111 & - \\
\hline 8 & Dhirubhai Ambani & - \\
\hline
\end{tabular}




\begin{tabular}{|l|l|l|l|}
\hline & Communication Technology, Gujrath & & \\
\hline 9 & Sikkim Manipal University, Sikkim of Petroleum and Energy Studies, & 139 & - \\
\hline 10 & $\begin{array}{l}\text { University of } \\
\text { Uttarakhand }\end{array}$ & - \\
\hline 11 & Assam Don Bosco University, Assam & 152 & - \\
\hline 12 & Dr. C.V. Raman University, Chhattisgarh & 167 & - \\
\hline 13 & Ganpat University, Gujarat & 170 & - \\
\hline 14 & Manav Rachna International University, Haryana & 180 & - \\
\hline 15 & Manipal University, Rajasthan & 181 & - \\
\hline 16 & Sharda University, Uttar Pradesh & 189 & - \\
\hline 17 & Teerthanker Mahaveer University, Uttar Pradesh & 193 & - \\
\hline
\end{tabular}

Table 6 : List of private universities included in NIRF-2017 Best Management Institution ranking

\begin{tabular}{|l|l|l|l|}
\hline $\begin{array}{l}\text { S. } \\
\text { No. }\end{array}$ & Name of the University & Rank (100) & $\begin{array}{l}\text { Parameter Based } \\
\text { Strength }\end{array}$ \\
\hline 1 & Nirma University & 31 & $45.81 \%$ \\
\hline 2 & Xavier University & 33 & $44.85 \%$ \\
\hline 3 & Integral University & 82 & - \\
\hline 4 & PES University & 92 & - \\
\hline
\end{tabular}

\section{FEE CHARGING STRATEGY OF INDIAN PRIVATE UNIVERSITIES :}

Since private universities are self financing institutions, their annual revenue is mainly dependent on their fee collection strategy by offering innovative futuristic and demand based courses. Depending upon the location, infrastructure, quality, innovation, and placement service provided, private universities collect a different amount of annual course fees. Based on observation on fee collection for different courses, the fee-charging strategy of private universities can be divided into Low feeslow cost strategy, High cost-high quality strategy, and Nominal fees-High quality strategy.

6.1 Low Fees - Low cost Strategy :

Many private universities follow low-fees and low-cost strategy as listed in Table 7. This is mainly due to the heavy competition from Public Universities in neighbourhood. Some of the private universities which have substantially low infrastructure also follow this strategy to attract students of low income background. Such programmes usually contain less innovations in terms of value additions, quality of infrastructure, and academic vigorous. Private universities like Techno Global University of Meghalaya, Integral University of Lucknow, Uttar Pradesh, Singhania University of Rajasthan, and Monad University of Uttar Pradesh, and MATS University of Raipur, Chhattisgarh, are charging less than Rs. 50,000 for B.Tech programmes annually. Similarly, the Universities like Dr. C.V. Raman University of Bilaspur, Chhattisgarh, Kadi Sarva Vishwavidyalaya of Gujarat, Techno Global University of Meghalaya, The Global Open University of Nagaland, Shri Jagdish Prasad Jhabarmal Tibrewala University of Rajasthan, Monad University of Uttar Pradesh, Singhania University of Rajasthan are charging less than Rs. 50,000 as an annual fee for MBA programmes.

Table 7 : List of Private Universities started before 2010 which follow Low Fee - Low cost strategy

\begin{tabular}{|l|l|l|l|}
\hline S.No & Name of the Private University & $\begin{array}{l}\text { Annual Fee for } \\
\text { B.E/B.Tech }\end{array}$ & $\begin{array}{l}\text { Annual Fee for } \\
\text { MBA }\end{array}$ \\
\hline 1 & Assam Down Town University & 70,000 & $1,25,000$ \\
\hline 2 & Dr. C.V. Raman University & nil & 51,500 \\
\hline 3 & Mats University & 30,000 & 70,000 \\
\hline 4 & Ganpat University & 87,000 & 81,000 \\
\hline 5 & Kadi Sarva Vishwavidyalaya & nil & 42,000 \\
\hline 6 & Manav Bharti University & 82,500 & 75,000 \\
\hline
\end{tabular}

P. S. Aithal et al. (2017); www.srinivaspublication.com 


\begin{tabular}{|c|c|c|c|}
\hline 7 & Indus International University & 94,500 & $1,10,000$ \\
\hline 8 & $\begin{array}{l}\text { The Institute Of Chartered Financial } \\
\text { Analyst Of India University }\end{array}$ & 87,500 & $1,15,500$ \\
\hline 9 & CMJ University & 50,000 & 60,000 \\
\hline 10 & Techno Global University & 36,000 & 30,000 \\
\hline 11 & The Global Open University & nil & 14,462 \\
\hline 12 & $\begin{array}{l}\text { Sri Guru Granth Sahib World } \\
\text { University }\end{array}$ & 86,000 & 86,000 \\
\hline 13 & Bhagawath University & 61,000 & 60,000 \\
\hline 14 & Dr K.N. Modi University & 94,900 & 95,800 \\
\hline 15 & $\begin{array}{l}\text { Jaythi Vidyapeeth Women's } \\
\text { University }\end{array}$ & 90,000 & 90,000 \\
\hline 16 & Jodhpur National University & 90,000 & 68,000 \\
\hline 17 & $\begin{array}{llll}\begin{array}{l}\text { Mahatma } \\
\text { University }\end{array} & \text { Jyoti } & \text { Rao } & \text { Phoole } \\
\end{array}$ & 71,000 & 61,000 \\
\hline 18 & Mewar University & 88,000 & 78,000 \\
\hline 19 & NIMS University & 66,500 & 75,000 \\
\hline 20 & $\begin{array}{l}\text { Shri Jagdish Prasad Jhabarmal } \\
\text { Tibrewala University }\end{array}$ & 70,000 & 50,000 \\
\hline 21 & Shridhar University & 83,000 & 87,000 \\
\hline 22 & Singhania University & 41,000 & 41,300 \\
\hline 23 & Integral University & 35,000 & 50,000 \\
\hline 24 & Mohammad Ali Jauhar University & 69,000 & 55,000 \\
\hline 25 & Monad University & 21,300 & 48,600 \\
\hline 26 & Shri Venkateshwara University & 70,000 & 65,000 \\
\hline 27 & $\begin{array}{l}\text { Swami Vivekanand Subharti } \\
\text { University }\end{array}$ & 75,000 & $1,00,000$ \\
\hline 28 & Himgiri Zee University & 85,000 & $1,50,000$ \\
\hline
\end{tabular}

The Private universities with a low-fee- low-cost strategy provide education at a minimal cost to the student. Their main aim is to provide basic and normal education at minimum cost so that it can reach to the people. Table 7 includes private universities who offer B.Tech programme for an annual fee below Rs. 1,00,000 and MBA programme annual fee below Rs. 1,50,000.

\subsection{High Fees -High Quality Strategy:}

Some of the private universities started before the year 2010 also follow High-Fee - High-quality strategy as shown in Table 8 . The Table 8 depicts only the sample fees charged by such universities for their B.Tech. and MBA programmes. It is found that so many universities, Alliance University of Bangalore, Nirma University of Gujarat, O.P. Jindal Global University of Haryana, and University of Petroleum and Energy Studies of Uttarakhand are charging more than Rs. 5,00,000 annual fee for MBA programme and Sikkim-Manipal University of Sikkim, Sharda University of Uttar Pradesh, University of Petroleum and Energy Studies of Uttarakhand, G.D. Goenka University of Haryana, and PES University Bangalore are charging more than Rs. 2,00,000 annually for their B.Tech. Programmes. These universities have differentiated themselves either through their brand image 
which has been built from intensive quality initiatives from a long time, or massive infrastructure, or Training through foreign faculty members, or through one semester abroad, or offering high tech elective papers through industry tie-up etc. The table 8 lists only the universities who charge an annual fee of Rs. 1,50,000 and above for their B.Tech programme and an annual fee of Rs. 2,50,000 and above for their MBA programme.

Table 8 : List of universities started before 2010 which follow 'High cost - High quality’ Strategies

\begin{tabular}{|l|l|l|l|}
\hline S.No & Name of the Universities & \multicolumn{1}{|c|}{$\begin{array}{c}\text { Annual Fee for } \\
\text { B.Tech }\end{array}$} & Annual fee for MBA \\
\hline 1 & Alliance University & $1,80,000$ & $6,75,000$ \\
\hline 2 & Nirma University & $1,57,725$ & $5,46,000$ \\
\hline 3 & O.P. Jindal Global University & - & $5,50,000$ \\
\hline 4 & Amity University, MP & $1,50,000$ & $2,77,075$ \\
\hline 5 & Lovely Professional University & $1,89,000$ & $2,50,000$ \\
\hline 6 & Amity University, Rajasthan & $1,55,000$ & $2,62,000$ \\
\hline 7 & Sikkim- Manipal University & $2,42,000$ & $2,70,000$ \\
\hline 8 & Amity University UP & $1,85,000$ & $4,27,000$ \\
\hline 9 & Sharda University & 2,05000 & $2,50,000$ \\
\hline 10 & $\begin{array}{l}\text { University of Petroleum and Energy } \\
\text { Studies }\end{array}$ & $3,37,500$ & \\
\hline 11 & G.D Goenka University, Haryana & $2,15,000$ & $5,57,000$ \\
\hline 12 & PES University, Bangalore & $3,00,000$ & $3,95,000$ \\
\hline 13 & $\begin{array}{l}\text { Jaypee University of Information } \\
\text { Technology }\end{array}$ & $1,82,500$ & $4,00,000$ \\
\hline
\end{tabular}

\subsection{Nominal Fees - High-Quality Strategy :}

Apart from the conventional strategies of low-fee low quality, and high-fee - high-quality, there are some philanthropic private universities charges nominal fees for bright students without compromising high quality. Some of the private universities which follow such strategy are listed in Table 9 with a sample of annual fees charged for their B.Tech. and MBA programmes. Many of private universities in Table 9 charges nearly Rs. 1,00,000 for B.Tech programmes and between Rs. $1,00,000$ to Rs. 2,00,000 for MBA programmes. Many of these universities are financially supported by either Charitable Trust or through public donations and contributions. Table 9 includes private universities who have quality education for a nominal fee. Nominal fee falls under the category of Rs.1,00,000 to Rs.2,50,000 which is decent fee structure and affordable for many of the students. These are the universities which are offering good quality education with nominal fees and are established on or before 2010 and reached many students all over the world by their quality, commitment, and fee structure.

Table 9 : List of universities started before 2010 which follow 'Nominal Fees - Highly Quality Strategies'

\begin{tabular}{|l|l|l|l|l|}
\hline S.No & Name of the Private University & $\begin{array}{l}\text { Annual Fee for } \\
\text { B.E/B.tech }\end{array}$ & $\begin{array}{l}\text { Annual Fee for } \\
\text { MBA }\end{array}$ \\
\hline 1 & Assam Don Bosco University & $1,36,000$ & $1,90,500$ \\
\hline 2 & Ahmadabad University & $1,07,500$ & $1,29,250$ \\
\hline 3 & $\begin{array}{l}\text { Charotar University Of Science And } \\
\text { Technology }\end{array}$ & $1,35,000$ & $1,35,000$ \\
\hline
\end{tabular}




\begin{tabular}{|l|l|l|l|} 
& $\begin{array}{l}\text { Dhirubhai Ambani Institute Of } \\
\text { Information And Communication } \\
\text { Technology }\end{array}$ & $1,35,000$ & \\
\hline 5 & Navrachana University & $1,15,000$ & Nil \\
\hline 6 & Apeejay Stya University & $1,64,200$ & $1,50,000$ \\
\hline 7 & Chitkara University & $1,54,000$ & $2,16,200$ \\
\hline 8 & $\begin{array}{l}\text { The Institute Of Chatered Financial } \\
\text { Analyst Of India University }\end{array}$ & Nil & $2,23,000$ \\
\hline & $\begin{array}{l}\text { Jaypee University Of Engineering And } \\
\text { Technology }\end{array}$ & $1,87,500$ & $1,02,000$ \\
\hline & $\begin{array}{l}\text { The Institute Of Chatered Financial } \\
\text { Analyst Of India University }\end{array}$ & - & Nil \\
\hline 11 & Jagannath University & $1,06,000$ & $1,07,000$ \\
\hline 12 & Jaipur National University & $1,30,000$ & $1,83,000$ \\
\hline 13 & G.L.A. University & $1,58,250$ & $1,30,000$ \\
\hline 14 & SRM University, Haryana & $2,16,000$ & $1,58,000$ \\
\hline
\end{tabular}

\subsection{Private Universities with Medical Courses :}

Some of the private universities have started medical courses at undergraduate and postgraduate level. The financial status and hence the investment abilities of such universities are considered to be high improving and growing in terms of their infrastructure at a faster pace. Table 10 contains the list of private universities which offers medical and Paramedical courses at undergraduate and postgraduate level.

Table 10 : List of Private Universities started before 2010 having Medical Courses including MBBS

\begin{tabular}{|l|l|l|l|l|}
\hline S.No & Name of the Private University & $\begin{array}{l}\text { Annual Fee for } \\
\text { MBBS }\end{array}$ & B.TECH & MBA \\
\hline 1 & Maharishi Markamdeshwar University & $5,00,000$ & 80,000 & 70,000 \\
\hline 2 & Sikkim- Manipal University & $12,20,000$ & $2,42,000$ & $2,70,000$ \\
\hline 3 & Integral University & $15,00,000$ & 35,000 & 50,000 \\
\hline 4 & Sharda University & $11,40,000$ & $2,05,000$ & $2,50,000$ \\
\hline 5 & $\begin{array}{l}\text { Swami Vivekanand Subharti } \\
\text { University }\end{array}$ & $9,35,500$ & 75,000 & $1,00,000$ \\
\hline 6 & Teerthanker Mahaveer University & $16,70,000$ & $1,28,600$ & $1,59,200$ \\
\hline
\end{tabular}

The above-mentioned table shows the universities having MBBS course along with B.Tech and MBA established on or before 2010 in India with low fee-low cost strategy and High fee- quality education strategy.

\section{ADVANTAGES FOR PRIVATE UNIVERSITIES FOR INNOVATIONS \& BEST PRACTICES :}

Irrespective of financial constraints and lack of support from the government for infrastructure, the recently started private universities in India are doing exceptionally good in terms of designing and offering innovative industry-oriented customized programmes to their students. By designing superspecialized and customized programmes private universities are attracting students for quality education. Some of the observed innovations of private universities are listed in Table 11.

Table 11 : Advantages of innovations and best practices offered by Private universities for students 


\begin{tabular}{|c|c|c|}
\hline S. No. & Innovation & Advantages to Students \\
\hline 1 & $\begin{array}{l}\text { Providing laptop to } \\
\text { the students }\end{array}$ & $\begin{array}{l}\text { Improve the technical aspects and also platform to gather } \\
\text { knowledge. }\end{array}$ \\
\hline 2 & $\begin{array}{l}\text { Classrooms with } \\
\text { LCD }\end{array}$ & Pictorial examples and easy understanding. \\
\hline 3 & $\begin{array}{l}\text { College website or } \\
\text { app }\end{array}$ & $\begin{array}{l}\text { Updated attendance and syllabus material which can be uploaded } \\
\text { by teacher can be downloaded by students }\end{array}$ \\
\hline 4 & $\begin{array}{l}\text { Open book } \\
\text { examination }\end{array}$ & $\begin{array}{l}\text { Improve the knowledge of the students in application based } \\
\text { questions }\end{array}$ \\
\hline 5 & $\begin{array}{l}\text { Online submission } \\
\text { of assignments }\end{array}$ & Make students punctual in submission. \\
\hline 6 & Online examination & $\begin{array}{l}\text { Examination conducted on the system in order save time and } \\
\text { waste of paper and also make correction easier. }\end{array}$ \\
\hline 7 & Result & $\begin{array}{l}\text { Published through college application which helps the students to } \\
\text { know individual results on their account. }\end{array}$ \\
\hline 8 & $\begin{array}{l}\text { Online Open } \\
\text { education }\end{array}$ & $\begin{array}{l}\text { It helps students from anywhere and anybody to avail } \\
\text { education. }\end{array}$ \\
\hline 9 & $\begin{array}{l}\text { Choice Based Credit } \\
\text { System }\end{array}$ & $\begin{array}{l}\text { Students can choose the subjects as per their preference to earn } \\
\text { required credit. }\end{array}$ \\
\hline 10 & $\begin{array}{l}\text { Competency-based } \\
\text { Credit System }\end{array}$ & $\begin{array}{l}\text { Students have to earn required competency to pass a subject or } \\
\text { degree. There is no fixed time frame to complete a course. } \\
\text { Students may have their own pace of learning. }\end{array}$ \\
\hline 11 & $\begin{array}{l}\text { Continuous } \\
\text { assessment } \\
\text { examination system }\end{array}$ & $\begin{array}{l}\text { Assessments in the form of exams are spread over the course } \\
\text { instead of course end exam only. Students have no pressure to } \\
\text { remember the entire semester or year curriculum during the final } \\
\text { exam. }\end{array}$ \\
\hline 12 & $\begin{array}{l}\text { Dual Degree } \\
\text { Programmes }\end{array}$ & $\begin{array}{l}\text { Students can register two courses simultaneously and get } \\
\text { graduation in both areas. This allows them to utilize their time } \\
\text { effectively to earn multiple degrees. }\end{array}$ \\
\hline 13 & $\begin{array}{l}\text { Student Exchange } \\
\text { Programs }\end{array}$ & $\begin{array}{l}\text { Through exchange of a group of students between different } \\
\text { cultures/social environment, students can get exposure and learn } \\
\text { to become a better decision maker. }\end{array}$ \\
\hline 14 & $\begin{array}{l}\text { Semester Abroad } \\
\text { System }\end{array}$ & $\begin{array}{l}\text { Wide exposure and skill development leading to the enhanced job } \\
\text { opportunity. }\end{array}$ \\
\hline 15 & $\begin{array}{l}\text { Earn while learn } \\
\text { model }\end{array}$ & $\begin{array}{l}\text { Students get working experience, enhanced participation and } \\
\text { responsibility in the classroom, and realize the value for money. }\end{array}$ \\
\hline
\end{tabular}

\section{RECOMMENDATIONS :}

The following recommendations are proposed based on observations and analysis of private universities admission, service, research, and annual fee strategies.

1. Private universities should focus on providing high-quality education to the students at affordable cost.

2. Private universities should focus on creating innovators by adding research components in their curriculum.

3. Private universities should use the autonomy given to them effectively to continuously update their curriculum which is not possible for public sector universities due to lengthy bureaucratic procedures involved in the approval process.

4. Investment in infrastructure and providing awesome facilities will allow the private universities to follow high-fee high-quality strategy still will be able to attract more students.

5. Innovations discussed in Table 11 will give competitive advantages to private universities to improve their brand image. 
6. Private universities with medical courses at the undergraduate and postgraduate level will be able to follow low fee but the high-quality strategy in non-medical courses due to their financial ability to invest more to improve the infrastructure.

7. Private universities should focus on research and publications along with forming the strategy to creating academic Excellency like top private universities in the USA.

8. Private universities in India also follow the path of Top Private Research universities in the USA by following a strategy of not for profit slogan and attracting highly qualified faculty members from all around the country and abroad.

9. Private universities should focus on the involvement of undergraduate and postgraduate students in research by adding one or more research-based subjects in the curriculum and compulsory publications as necessary requirements for awarding degrees.

10. Private universities which have started many programmes under several faculties as shown in Table 4 can serve more people in the society by offering higher education in wider and specialized areas. This will also contribute to the country through added multi-disciplinary research and publications in many fields.

11. Private universities should also focus their innovative strategy on various parameters of NIRF Ranking of the country. Focus on faculty developments, appointing research background faculties with research degrees and proven research and publication records, encouraging faculty members for active research by setting up university funded research centres, appointing star achievers in research as role-models for young researcher gives added advantage to establish name and fame to attract global students to the universities.

12. Offering super specialization courses with industry involvement allows universities to follow high fee high-quality strategy and still attracts many students.

13. It trains the students by providing the best quality teacher and facilities which is available.

14. They also try to improve the quality of their working by introducing new ideas in order to be the best among other private universities.

15. Continuous innovation and brand building by globalizing the student admission and faculty recruitments will improve the societal perspective of the universities.

16. Offering dual degree programmes to the students both at under graduation and post graduation level will be more attractive due to the reason that students get the opportunity to become multidisciplinary experts without wasting valuable time in their young period of life.

Since the private universities have a comparative advantage with autonomy to make innovations, they can grow and establish as an effective university and institution of eminence in a short time. As time progress, there will be many private universities in better NIRF ranking umbrella with the improved parameter based performance which is presently low as seen in Tables $5 \& 6$.

\section{CONCLUSION :}

The study focuses on identifying state-wise private universities in India, separating age based performance, and faculties expansion strategies in private universities, private universities identified under NIRF ranking and their parameter based performance, annual fee charging strategy followed by different private universities in India. It also helps to understand which all universities provide their maximum quality services to their students. We have also studied the performance scores given by NIRF, MHRD, Govt. of India for various criterions like Teaching, Learning \& Resources, Research and Professional Practice, Graduation Outcomes, Outreach and Inclusivity, Public Perception. It is found that only few private universities till now found place in NIRF ranking and there is ample scope to progress further through effective completion in terms of quality improvement both at academic performance and research output. It is seen that private universities in India follow various strategies to face the competition and attract students for different courses. This includes low-fee low-quality strategy, Low-fee high-quality strategy, and High-fee High-quality strategy. The paper also identified various quality strategies followed by Indian old private universities (started on or before 2010) to charge low, average and high annual fees for their B.Tech and MBA programmes. Many innovative strategies followed by these universities to attract more students are also identified and listed. 


\section{REFERENCES :}

[1] https://www.topuniversities.com/university-rankings-articles/world-university-rankings/topuniversities-us-2018 retrieved on 05/12/2017.

[2] Agarwal, P. (2007). Higher education in India: Growth, concerns, and change agenda. Higher Education Quarterly, 61(2), 197-207.

[3] Angom, S. (2015). Private Higher Education in India: A Study of Two Private Universities. Higher Education for the future, 2(1), 92-111.

[4] Aithal, P. S. \& Suresh Kumar, P.M. (2016). Opportunities and Challenges for Private Universities in India, International Journal of Management, IT and Engineering (IJMIE), 6(1), 88-113. DOI : http://doi.org/10.5281/zenodo.161157.

[5] Aithal, P. S. \& Suresh Kumar, P. M. (2016). Innovations in Private Universities : A Case of Srinivas University, International Journal of Management, IT and Engineering (IJMIE), 6(1), 250-264, DOI : http://doi.org/10.5281/zenodo.161151.

[6] Aithal, P. S. \& Shubhrajyotsna Aithal, (2016). Impact of On-line Education on Higher Education System, International Journal of Engineering Research and Modern Education (IJERME) 1(1), 225-235, DOI : http://doi.org/10.5281/zenodo.161113.

[7] Aithal, P. S., Shailashree, V. T. \& Suresh Kumar, P.M. (2016). Application of ABCD Analysis Framework on Private University System in India. International Journal of Management Sciences and Business Research (IJMSBR), 5, 4, 159-170, DOI : http://doi.org/10.5281/zenodo.161111.

[8] Paul, P. K., Aithal, P. S., Bhuimali, A. (2017). Computing \& Allied Engineering Domain in India with reference to Private Universities: A Case Study of Bachelors Programs. International Journal on Recent Researches In Science, Engineering \& Technology, 5(11), 51-66. DOI : http://dx.doi.org/10.5281/zenodo.1089937.

[9] Aithal, P. S., \& Shubhrajyotsna Aithal, (2015). An Innovative Education Model to realize Ideal Education System. International Journal of Scientific Research and Management (IJSRM), 3(3), 2464 - 2469, DOI: http://doi.org/10.5281/zenodo.61654.

[10] Aithal, P. S., Srinivas Rao, A. S. \& P.M. Suresh Kumar, (2015). Quality Enhancement in Higher Education Institutions : A case study of SIMS, International Journal of Multidisciplinary Research and Development, 2(5), 18-31, DOI: http://doi.org/10.5281/zenodo.266940.

[11] Aithal, P. S. (2015). Strategy Development and Deployment in Higher Education Institutions, Elixir International Journal, 84, 3594 - 33597, DOI: http://doi.org/10.5281/zenodo.266779.

[12]. Aithal, P.S., (2015) Comparative Study on MBA Programmes in Private \& Public Universities A case study of MBA programme plan of Srinivas University. International Journal of Management Sciences and Business Research (IJMSBR), 4(12), 106-122. DOI : http://doi.org/10.5281/zenodo.163884.

[13] Aithal \& Jeevan Pinto, (2016). Innovations in Higher Education - A new model implemented in MCA degree programme of Srinivas University, International Journal of Scientific Research and Modern Education (IJSRME), 1(1). 275-289. DOI : http://doi.org/10.5281/zenodo.161107.

[14] Aithal, P. S. \& Suresh Kumar, P. M. (2015). Enhancement of Graduate attributes in Higher Education Institutions through Stage Models. IMPACT: International Journal of Research in Business Management, 3(3), 121 - 130. DOI: http://doi.org/10.5281/zenodo.61640.

[15] Aithal, P. S., Srinivas Rao, A. \& Suresh Kumar, P. M. (2015). Quality Enhancement in Higher Education Institutions : A case study of SIMS. International Journal of Multidisciplinary Research and Development, 2(5), 18-31. DOI: http://doi.org/10.5281/zenodo.266940. 
[16] Aithal, P. S. (2015). Strategies to be adopted in Higher Education Institutions to Enhance Admission Demand. International Journal of Extensive Research, 5, 9-25. DOI: http://doi.org/10.5281/zenodo.268530.

[17] Aithal, P. S. (2015). MBA++ as a Unique \& Successful Model in Integrated Development of Business Executives. International Journal of Management, IT and Engineering (IJMIE), 5(7), 124-133. DOI: http://doi.org/10.5281/zenodo.266987.

[18] Aithal, P. S. \& Suresh Kumar, P. M. (2015). Applying SWOC Analysis to an Institution of Higher Education. International Journal of Management, IT and Engineering (IJMIE), 5(7), 231247. DOI : http://doi.org/10.5281/zenodo.163425.

[19] Aithal, P. S., Suresh Kumar, P. M. \& Deekshitha, (2015). Societal Expectation and Institutional Accountability In Higher Education. International Journal of Management, IT and Engineering (IJMIE), 5(7), 361-373. DOI : http://doi.org/10.5281/zenodo.267021.

[20] Aithal, P. S. \& Priti Jeevan, (2016). Strategic Rethinking of Management Education : Green MBA Model. International Journal of Management, IT and Engineering (IJMIE), 6 (1), 55-73. DOI : http://doi.org/10.5281/zenodo.154278.

[21] Aithal, P. S (2016). Creating Innovators through setting up organizational Vision, Mission and Core Values : a Strategic Model in Higher Education. International Journal of Management, IT and Engineering (IJMIE), 6(1), 310-324. DOI : http://doi.org/10.5281/zenodo.161147.

[22] Aithal, P. S., Shailashree, V. T. \& Suresh Kumar, P.M. (2016). The Study of New National Institutional Ranking System using ABCD Framework. International Journal of Current Research and Modern Education (IJCRME), 1(1), 389 - 402. DOI : http://doi.org/10.5281/zenodo.161077.

[23] Aithal, P. S. \& Suresh Kumar, P. M. (2016). Teaching - Learning Process in Higher Education Institutions. International Journal of Multidisciplinary Research and Modern Education (IJMRME), 2(1), 662-676. DOI : http://doi.org/10.5281/zenodo.160956.

[24] Prithi Rao, and Aithal, P. S. (2016). Green Education Concepts \& Strategies in Higher Education Model. International Journal of Scientific Research and Modern Education (IJSRME), 1(1), 793-802. DOI : http://doi.org/10.5281/zenodo.160877.

[25] Aithal, P. S. and Sonia D. N. (2016). Hitting Two Birds with One Stone : Srinivas University B.Com. Model in Corporate Auditing, International Journal of Scientific Research and Modern Education (IJSRME), 1(1), 853-869. DOI : http://doi.org/10.5281/zenodo.154602. 